\title{
American Board of Family Medicine Selects New Chief Executive Officer and President
}

\section{Jane Ireland}

The American Board of Family Medicine's (ABFM) Board of Directors has selected Warren Newton, MD, MPH to become its next President and Chief Executive Officer, succeeding Dr. James C. Puffer on his retirement. Dr. Newton will serve in the position of President and CEO Elect beginning July 1, 2018 upon Dr. Puffer's retirement at the end of 2018. On assuming the role of President and CEO on January 1, 2019, Dr. Newton will oversee the ABFM, as well as the ABFM Foundation and Pisacano Leadership Foundation.

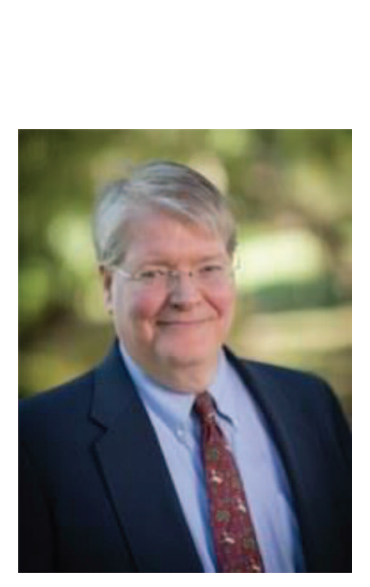

\section{About Dr. Newton}

Dr. Newton is currently Executive Director of the North Carolina Area Health Education Center (NC AHEC), a national leader in practice redesign, continuing professional development, health careers programming, and innovation in graduate medical education, and Vice Dean of the School of Medicine at the University of North Carolina (UNC). From 1999 to 2016, he served as the William B. Aycock Professor and Chair of Family Medicine at UNC.

Dr. Newton has been a personal physician for 33 years, working in a variety of settings, including the UNC Family Medicine Center, the Moncure Community Health Center, and the Randolph County Health Department. In the 1990s, he founded the first hospitalist program at UNC Hospitals and helped reorganize family medicine obstetrics into a maternal child service. Over the past

Conflict of interest: The author is an employee of the ABFM.
15 years, he has led practice transformation initiatives at the practice, regional and statewide levels; North Carolina AHEC now provides support in health information technology, Patient-Centered Medical Home (PCMH), and quality improvement for over 1200 primary care practices.

As an educator, Dr. Newton served as residency director at UNC from 1992 to 1997; since 2004, he has colead the I3 collaborative of 24 primary care residencies focused on clinical transformation in the residency practices. He has also taught extensively in medical school and fellowship programs and served as Vice Dean of Medical Education at the UNC from 2008 to 2013, during which he led an Liaison Committee On Medical Education (LCME) review, expanded the school, established satellite campuses, developed new curricula in professionalism and population health and expanded the enrollment of underrepresented minorities. Dr. Newton's scholarship has focused on the organization and effectiveness of health care; he has over 140 peer reviewed publications, including over 80 published with students, and has been principal investigator on grants totaling more than $\$ 45,000,000$. Finally, from 2012 to 2017, he served on the Board of Trustees of the North Carolina State Health Plan, responsible for the health and health care of approximately 700,000 state and county employees and retirees. In 2016, he served as Senior Policy Advisor to the North Carolina Secretary of Health and Human Services, helping to prepare the Medicaid 1115 innovation waiver, plan rural residency expansion and develop quality metrics for Medicaid.

"Warren Newton's extraordinary service to the discipline of family medicine and his commitment to improving health has been a core value that has guided every aspect of his professional work over the last 3 decades," said Elizabeth G. Baxley, MD, Professor of Family Medicine at Brody School of 
Medicine and Chair of the ABFM Board. "I have had the privilege of working with Warren at the state and national level and can attest to his dedication to continuous improvement and innovation in clinical care and education, as well as his drive to strengthen the discipline of family medicine to serve the American public. He is truly a transformative leader, and the ABFM Board of Directors is confident in his abilities to ensure that our certification programs are relevant and worthwhile to both clinicians and patients."

Continuously board certified in family medicine since 1987, Dr. Newton served on the ABFM Board of Directors from 2007 to 2013, including his term as Board Chair in 2011 to 2012. He currently serves as a Director on the ABFM Foundation Board of Directors. Dr. Newton also brings experience working with the American Board of Medical Specialties (ABMS), where he serves as a member of the ABMS Committee on Continuing Certification, including a term as one of its first chairs in 2014.

Additional national roles in which Dr. Newton has served include President of the Association of Departments of Family Medicine and Founding Chair of the Council of Academic Family Medicine. He is currently a member of the Liaison Committee of Medical Education and represents the ABFM at the National Academy of Medicine's Global Forum on Innovation in Health Professional Education.

Dr. Newton graduated from Yale University in 1980 and Northwestern Medical School in 1984. After residency and chief residency at the UNC, he completed the Robert Wood Johnson Clinical Scholars Program and an MPH at the UNC Gillings School of Global Public Health. In 2012 to 2013, he was selected as a Society of Teachers of Family Medicine Bishop Fellow, during which he also completed the American Council of Education Fellow's program.
"For nearly 50 years, the American Board of Family Medicine has served family physicians and the public with great distinction. I am delighted to serve the Board and family physicians across the country and honored to follow the outstanding leadership of Jim Puffer," said Newton. "I have great admiration for the family physicians at the forefront of the care and the innovation that the American public needs. The Board is deeply committed to supporting them as they serve their patients and communities, and will continue to help develop the systems and tools needed to support them as they work continually to improve their practices. We are also committed to engagement with our partnerspatients and families, other specialties, other professions, other organizations and payers-who share our vision of the need for dramatic improvement in health and health care for the American people."

\section{About ABFM}

ABFM is one of the 24 Member Boards of the American Board of Medical Specialties. Founded in 1969 , it is a voluntary, not-for-profit, private organization whose objective is to encourage excellence in medical care. The ABFM believes that its certified family physicians have successfully demonstrated their ability and have proven their commitment to the public, the specialty of Family Medicine and the profession.

Through its certification processes, the ABFM seeks to provide patients the assurance that their certified family physicians have the necessary education, training, skills and experience to provide high-quality care to patients and their families and that this commitment to excellence is maintained throughout their years of practice.

To see this article online, please go to: http://jabfm.org/content/ 31/1/169.full. 